\title{
Official Media Discourse of 'Active Longevity': an Attempt to Popularize the Idea of the Inclusion of Older People into Society or to Conceal Undesirable Forced Choices
}

\author{
Anastasiya Jurkevits \\ Lithuanian Social Research Centre - anastasiya.jurkevits@gmail.com
}

\begin{abstract}
In the process of reforming social policies, various actors use media channels to convey their arguments to a wide audience and popularize certain ideas. Not only facts are transmitted, but also a certain image of social reality. This paper explores the main media narratives of the official discourse of active longevity' in Belarus in the period 2017-2018, with the aim to explore the meanings that they broadcast in society, and what the image of social reality they represent and construct. For the analysis of narratives, semantic content analysis is used, as well as qualitative discourse analysis of texts/articles of The Belarusian Telegraph Agency BelTA and The Belarus Segodnia ('Belarus Today') state publishing house incorporated five newspapers. Texts were sampled for the period 1 January 2017 to

in the materials of the official media, together with the comments of journalists, show the activity of older people as a desirable version of reality, as well as their rarity and non-typicality for the contemporary Belarusian society. This conclusion suggests that in this discourse, exactly the official narrative of 'active longevity' is the counter-story, designed to overcome the dominant in society popular and most shared narratives. The understanding of 'active longevity' offered by official discourse seems to be a simplified version of reality, focusing mainly on categories of labour activity, utility for the society or not burdening the society. This counter-narrative does not re-humanize, but instead of empowering it makes other choices for understanding 'active longevity' invisible and insignificant.
\end{abstract} 31 December 2018. The transmitted narratives

Keywords: Belarusian official discourse, active ageing, active longevity narratives, counter-narrative.

\section{O discurso oficial dos media sobre a "longevidade ativa": uma tentativa de popularizar a ideia da inclusão de pessoas idosas na sociedade ou de ocultar escolhas forçadas indesejáveis}

\section{Sumário}

No processo de reforma das políticas sociais, vários atores usam os canais dos media para transmitir os seus argumentos a um público amplo e popularizar certas ideias. Não apenas 
os factos são transmitidos, como também uma certa imagem da realidade social. Este artigo explora as principais narrativas mediáticas do discurso oficial da 'longevidade ativa' na Bielorrússia no período 2017-2018, com o objetivo de explorar os significados que eles transmitem na sociedade, e qual a imagem da realidade social que representam e constroem. Para a análise das narrativas, utiliza-se a análise de conteúdo semântico, assim como a análise qualitativa do discurso de textos / artigos da Agência Telegráfica da Bielorrússia BelTA e da editora estatal The Belarus Segodnia ( Belarus Today») incorporada em cinco jornais. Os textos foram recolhidos por amostra no período entre 1 de janeiro de 2017 e 31 de dezembro de 2018. As narrativas transmitidas nos materiais dos media oficiais, juntamente com os comentários dos jornalistas, mostram a atividade das pessoas idosas como uma versão desejável da realidade, bem como a sua raridade e não tipicidade para a sociedade bielorrussa contemporânea. Esta conclusão sugere que, neste discurso, exatamente a narrativa oficial da 'longevidade ativa' é a contra-história, projetada para superar as narrativas populares e mais comuns na sociedade. A compreensão da 'longevidade ativa' oferecida pelo discurso oficial parece ser uma versão simplificada da realidade, focada principalmente nas categorias de atividade laboral, de utilidade para a sociedade ou não sobrecarregando a sociedade. Essa contranarrativa não se re-humaniza, mas ao invés de fortalecê-la, faz outras escolhas para a compreensão da 'longevidade ativa' invisível e insignificante.

Palavras-chave: discurso oficial bielorrusso, envelhecimento ativo, narrativas de longevidade ativa, contra-narrativa.

\section{INTRODUCTION}

A person in the modern information space is immersed in many conflicting contexts created by both state authorities and the counter-contexts of various political forces, media resources, as well as regional and global contexts. Changing information contexts is an essential tool of 'soft power' affecting society (Nye, 2006). Business structures and political forces develop approaches to influencing the audience through the information flow of data, stories/narrations and visual landmarks or baits/appellants. Scientists note that although it is almost impossible to predict individual behaviour, collectives are predictable (Pentland, 2014). The design of informational contexts encompasses all large target groups, competing for the attention of an ever-expanding audience.

Media channels are important channels through which individuals receive not only factual information, but also a certain image of social reality. In the process of developing and reforming social policies, various actors interested in conveying their 
Official Media Discourse of 'Active Longevity': an Attempt to Popularize the Idea of the Inclusion of Older People into Society or to Conceal Undesirable Forced Choices

arguments and attracting as many supporters as possible need to think through the choice of facts and specific stories offered to an audience (Nye, 2006).

This task is no less important for the authorities. The main characteristics of the political field of Belarus (according to researchers) is a split into power and opposition parts with the president's dominant position as the main subject determining the institutional design of the entire political system and the content of the power narrative (Chulitskaya, 2014). Nevertheless, despite the problems and limitations associated with functioning in a non-democratic state (Balmaceda, 2014; Bassuener, 2013; HRC Viasna 2016, 2018), in the media space the competition of alternative information sources beyond the control of the state is growing, though the reach of state media is still dominant (BAJ, April - June 2016; 2019).

In the context of the implementation of pension reform and the implementation of unpopular changes in legislation on pension provisions, it requires serious explanatory work to reduce the level of dissatisfaction with the social policy being pursued while crisis trends in the economy persist. A legislative increase in the retirement age also entailed an adaptation of the 'active ageing/longevity' concept in the form of 'active longevity' and the popularization of the idea of revitalizing the elderly population. This discourse of 'active longevity' was permanently present in the official discourse of 2017 and received additional development in 2018, when officials announced the need to develop the concept of active longevity by the end of 2019 .

Global and regional problems of a socio-economic nature, the demographic situation in the country, as well as unfavourable forecasts by economists encourage/ stimulate the authorities to search for new solutions. The speeches of officials already contain assurances that they have taken into account the interests of all of the citizens and have worked out an optimal solution to the problem. The Minister of Labour and Social Protection I.A. Kostevich announced the development in 2019 of The National Strategy of 'Active Longevity' that will be created in the interests of senior citizens. The task of overcoming social stereotypes associated with ageing is stated (Respublica, 29.12.2018).

The concept of 'active ageing' (or 'active longevity') in foreign literature is not unambiguous. The World Health Organization defines 'active ageing' as 'the process of optimizing opportunities for health, participation and security in order to enhance quality of life as people age" (WHO, 2002). A detailed classification of various definitions was presented by Boudiny (2012) from unidimensional through multidimensional approaches to "transcending the behavioural level". He designated 
that active ageing is excessively understood in terms of stereotyped 'youthful' activities such as labour, care or sports (Boudiny, 2012, p. 1093). It is not only of interest what meanings are placed on them by representatives of the Belarusian state and what ideas they translate, but also what image of social reality is being constructed through official narratives.

This article explores the main media narratives of the official discourse of 'active longevity' in Belarus during the period of 2017-2018, with the aim of analysing the meanings that are broadcasted by them in society and the image of social reality they construct. We are interested in the use of 'soft power' by the state, in which the political stage has remained unchanged for more than two decades and requires a constant confirmation of its own legitimacy. In the context of global digitalization and the increasing share of alternative media in the information space, the power levers of government influence need to mobilize communication strategies to maintain their social policies and to form positive public opinion.

What social reality does the official discourse of 'active longevity' reflect and construct? What narratives are 'active longevity' are opposed to?

\section{THEORETICAL FRAMEWORK}

The importance of strategies for conveying information to the audience in achieving the targets set for the state or other subjects of communication was emphasized by V. $\mathrm{Vitto}_{2}$ who introduced the very concept of strategic communications (Vitto, 2001). The scientist raises the question of the vital importance of strategic communications for state security policy and stresses the need for a deeper study of cultures, relationships and networks of influence in the modern world, where traditional media capitulate/ give in to the influence of the Internet.

The idea of studying the communicative paradigm is supported by researchers from the RAND Corporation (Larson, Darilek, Gibran, Nichiporuk, Richardson, Schwartz, \& Thurston, 2009). They consider influence operations at the following levels: individual, group/network, enemy leaders, mass audience. As for the areas of influence, there are three directions: emotions, values, 'hot' cognitive processes; rational, cognitive and 'cold' processes; pressure for social obedience.

The study of media from the perspective of its ability to influence an audience and change its opinion began in the early 20th century, and today the power of 
Official Media Discourse of 'Active Longevity': an Attempt to Popularize the Idea of the Inclusion of Older People into Society or to Conceal Undesirable Forced Choices

this phenomenon is studied in various ways (Bennet \& Entman, 2001; Blumer \& Kavanagh, 1999; Gans, 2003; Graber \& Dunaway, 2017; Mayhew, 1997; Williams \& Michael, 2011). Some researchers explore not only the degree and ways media influences socio-political processes at different levels, but also "the influence of presumed influence" on a political process (Gunther \& Storey, 2003), thus arguing that the very belief in the significance of the media influences the actions and decisions of politicians. The President of the Republic of Belarus A. Lukashenko believes that the media is a weapon in the information war of the 21st century: "And, you know, these weapons are more powerful than nuclear ones. Because a small charge in the form of some news instantly covers the entire planet", and therefore, addressing Belarusian journalists, he added: "If we don't take possession of the minds and souls of Belarusians, we will never build a sovereign and independent country in such a classic form" (Grodno Regional Executive Committee, 2018).

The role of the media is not limited to informing, but extends to influencing through the formation of an information field, consisting either of facts and details selected by journalists and/or the formulation of stories/narrations with an emphasis placed on particular points. Thus, opinions are formed, a change in perception is developed, doubts begin to appear, and ultimately, the influence of change in audience behaviour becomes visible.

Back in 1990, J.S. Nye singled out the concept of 'soft power' as the ability of a state actor to shape the preferences of other actors through influencing public opinion without using violent means (Nye, 1990). Nye placed the main focus on attractiveness as a way to influence 'soft power' on public opinion (without using coercion) (Nye, 2006). Attractiveness is shaped by visual symbols, signals, utterances, and narratives distributed through various media channels. Strategies of 'soft power' and 'information operations' are often associated with the conduct of the information war (Porche, 2013), however, even in peacetime, various participants in the social policy development processes defend their ideas and interests, shaping and convincing the chosen audience with the help of statements, messages and narratives broadcast in the media space. And if hard power belongs to the state, then 'soft power' is not monopolized, and at the same time, according to L. Roselle, A. Miskimmon and B. O'Loughlin (2014), it can also coerce.

Here, the development of linguists and researchers of communicative processes proved useful when studying the problem of basic or strategic narratives that can formulate, influence and shape expectations (Miskimmon, 2013). Such narratives 
and counter-narratives affect one's perception of the world, sense of identity, and qualitatively alter the meanings of familiar social concepts and forms.

One of the definitions of a narrative in sociology is referred to as a conversation specially organized around consequential events (Mishler, 1986). An important feature of the narrative is the interweaving of the context into the text of the narrative: the position of the narrator and the listener (potential or real), the specific situation of the narration, the complex of social, historical and political conditions, taking into account this 'localization' and 'temporalization' of ideal meaning (Husserl, as cited in Merlo-Ponti, 1996, p. 63). Thus, the researcher must be not only familiar with the context but with the situation as well. And even though a consistent uniform definition of narrative has not yet been developed, and the narrative analysis itself is on the border of several areas of scientific knowledge, the analysis of narratives is actively used by sociologists. Narrative analysis, unlike ethnographic analysis, investigates the respondent's story not as a realistic description of facts and events, but as original personal reflections and interpretations of social reality (Pollner \& Stein, 1996). In turn, the analysis of media narratives puts us one step further from the facts described by the narrator, since the author of the material presents us with a selection of parts of personal stories supporting his or her idea. Thus, social reality is once again interpreted and constituted. And the discussion about the primary or secondary nature of language remains open: does language represent reality or does the narrative construct/constitute reality?

\section{RESEARCH DESIGN}

First of all, it should be noted why this study does not separately consider official legal documents, but focuses on the discourse of official media (which contains extracts from legal documents and their explanations by official persons). Documents are read directly only by some citizens, but news containing the interpretation of documents and excerpts from them, quotes, explanations by officials, etc. are the most widely read and discussed materials and that is perceived as an official discourse among the public.

The objective of this study is to analyse the official discourse field, which is formed by representatives of state authorities and state media channels. Based on the concept 
Official Media Discourse of 'Active Longevity': an Attempt to Popularize the Idea of the Inclusion of Older People into Society or to Conceal Undesirable Forced Choices

of governmentality (Foucault, 1991), it would seem necessary to investigate official policy documents and the statements of power actors. We do consider the official discourse as determining state priorities, but also see it to be a partial expression of values and attitudes prevalent in this particular society (at least among some voters). Therefore, the meanings and content of the concepts analysed in this article are considered both as products and as contributions to the contemporary Belarusian discourse.

In this study, the narrative is considered one of the most prevalent forms of communication (Fisher, 1978, 1984, 1987), especially in the media (Ryan \& Thon, 2014). It is also viewed as constituting reality and reproducing social reality through the prism of its experience, interests, and values (Berger \& Quinney, 2004; Czarniawska, 2004). An analysis of the meanings that official media as social actors endow to the concept of 'active longevity' is of paramount importance for us. Counter-narratives refers to narratives that have arisen from the viewpoint of historically marginalized groups against traditional domination (Bamberg \& Andrews, 2004).

Specific methods of analyzing narratives are diverse. In this study, semantic content analysis dominates and involves the systematization of units of text, depending on their meanings. "Media content-analysis is a specialized sub-set of content analysis, a well-established research methodology" and is widely used to study assorted/various 'texts' including the narrative (Macnamara, 2005, p. 1). Neuman (1997) explains content analysis as:

A technique for gathering and analysing the content of text. The 'content' refers to words, meanings, pictures, symbols, ideas, themes, or any message that can be communicated. The 'text' is anything written, visual, or spoken that serves as a medium for communication. (Neuman, 1997, pp. 272-273)

To justify the choice of data for analysis, the media context of the country and a description of two media organizations chosen for analyses were chosen: The Belarusian Telegraph Agency BelTA and The Belarus Segodnia ('Belarus Today'/BT) state publishing house were selected as they have the biggest turnout (official website of the Republic of Belarus, 2019).

Since 1995, the largest information agency of Belarus, BelTA, was given the first right to transmit official documents and messages to the media. The Belarus Segodnia ('Belarus Today'/BT) state publishing house is the largest modern multi- 
media holding in Belarus, which, in addition to the state radio station, includes five of the country's largest state newspapers: "SB. Belarus Today", "Narodnaya Gazeta", "Republic", "Selskaya Gazeta" and "Banner of Youth".

Human rights activists from the Independent Association of Journalists of Belarus have declared it urgent that the country solve a problem remaining from USSR times i.e. the forced subscription to state newspapers not only for state institutions, but also for private individuals (Belarusian Association of Journalists, 2019). In their annual reports since 2002, Reporters Without Borders have ranked_Belarus as one of the lowest for its level of freedom of the press; in 2019, Belarus has been ranked 153 out of 180 due to the "judicial harassment of freelance journalists» and "Internet censorship" (Reporters Without Borders, 2019). According to Rachel Denber, Deputy Director of the Europe and Central Asia Division at Human Rights Watch, "Belarusian authorities have a long and sorry history of contempt for media freedom" (Committee to Protect Journalists, 2019). However, access to the Internet provides an opportunity for the development of an independent Internet-media that creates serious competition for the government (Konstantinov, 2009).

The unit of analysis in this study consists of statements/phrases and the semantic extracts of texts, stories interpreting the concept of 'active longevity' ('active ageing') and related concepts. Fifty articles of the BelTA news agency and 81 articles of the The Belarus Segodnya (BT) were analyzed. In the search for materials, the keywords 'old age', 'old', 'elderly', 'retired', 'pensioner', 'old man/old woman', 'grandfather/ grandmother', 'ageing', 'longevity', 'active longevity' were used. Then the texts were read for compliance with a chronological framework and themes. Texts in which the above keywords were used only to indicate the age group of the participants of the described events and did not carry additional meanings were excluded from the analysis (mainly news from the criminal chronicle). For example, in an initial search of keywords for the period of January 1, 2017 to December 31, 2018, 469 articles were found on the website of the 'Belarus Today' Publishing House, containing keywords, phrases, and cognates in various cases, but only 81 articles were chosen for further research. 
Official Media Discourse of 'Active Longevity': an Attempt to Popularize the Idea of the Inclusion of Older People into Society or to Conceal Undesirable Forced Choices

Table 1

Selection of materials by keywords.

\begin{tabular}{|c|c|c|c|}
\hline \multicolumn{2}{|c|}{ Source of materials } & \multirow{2}{*}{$\frac{\text { BT }}{469}$} & \multirow{2}{*}{$\frac{\text { BelTA }}{84}$} \\
\hline \multirow{10}{*}{$\begin{array}{l}\text { Number of articles } \\
\text { found by keywords }\end{array}$} & old age ${ }^{*}$ & & \\
\hline & active $^{\star}$ longevity ${ }^{\star}$ ageing $^{\star}$ & 69 & 55 \\
\hline & aged $^{*}$ & 1172 & 931 \\
\hline & pensioner* & 1802 & 1000 \\
\hline & old man* & 796 & 123 \\
\hline & old woman ${ }^{\star}$ & 52 & 4 \\
\hline & $\operatorname{grandpa}^{\star} / \operatorname{granddad}^{*}$ & 932 & 186 \\
\hline & granny*/grandmother ${ }^{\star}$ & 2093 & 452 \\
\hline & long-liver* & 116 & 37 \\
\hline & old-aged $^{\star} /$ advanced in years ${ }^{*}$ & 344 & 237 \\
\hline Total found & & 7845 & 3109 \\
\hline Selected & & 81 & 50 \\
\hline
\end{tabular}

Note. Source: Field data

In the analysis of statements and stories of various subjects, narrative policy analysis was used as a subspecies of qualitative discourse analysis (Roy, 1994). Initially, all research materials were analysed to identify stories, non-stories, and counterstories, then a comparison was made of the stories and non-stories that form the metanarrative, and then the metanarratives and counter-narratives were identified. It is important to determine the content of the metanarrative and its central problem for understanding certain policy decisions and policymaking processes, as well as the social context of these decisions. 


\section{THE ADDRESSEES OF THE OFFICIAL NARRATIVE OF 'ACTIVE LONGEVITY’ AND THE EXPECTATIONS OF THE STATE}

First of all, it is necessary to note how powerful actors actualize the concept of 'active longevity' and represent their motivation for creating a strategy of 'active longevity' through an emphasis on demographic and economic trends in the country, as well as the latest medical advances and research by biologists and psychologists. The materials of state media and news agencies present an overall narrative of a conflictual situation that has arisen due to the disparity of traditional social attitudes with new realities in the modern context. It is precisely this discrepancy between obsolete stereotypes and the needs of individuals and society as a whole that is the cause and motivating force for policymakers who argue about the need to inform the population as a whole and to activate the elderly.

Attention to the concept of 'active longevity' by the media is caused by statements by state officials about the need to develop a national strategy by the same name. The officially published commentary to the Decree Concerning the Improvement of Pension Provisions on the website of the Ministry of Labour and Social Protection explains the main provisions of the regulatory legal act, and also expresses the goals pursued by the creators of the document. The decree provides for a set of measures "aimed at increasing the level of pensions of citizens who have reached the generally established retirement age, calculated with prolonged work experience, increasing the motivation of employees for a longer legal work activity and restricting dependent attitudes." ${ }^{\text {(Presidential Decree N. }}$ 570, 2014).

The development of a strategy of 'active longevity' is scheduled for 2019, but statements on this subject by officials and experts are actively appearing in the media. T. Fedorova, Deputy Head of the Main Department for Social Services and Social Assistance of the Ministry of Labour and Social Protection, said,

The strategy will be developed on the basis of the research work carried out by the Research Institute of Labour. Research in this area will allow to create a national age classification, determine who should be classified as elderly, what conditions for the development of the potential of senior citizens have already been created, suggest which areas need to be taken forward. (BT, 06.11.2018)

1 All quotes in the Belarusian or Russian languages were translated into English by the authors of the articles. 
Official Media Discourse of 'Active Longevity': an Attempt to Popularize the Idea of the Inclusion of Older People into Society or to Conceal Undesirable Forced Choices

From this voiced task, it is impossible to isolate the need to study the needs of the elderly as a heterogeneous group of people, but there is a noticeable desire to classify this category into age groups and offer opportunities for realizing the potential of these subgroups.

For this, experts working on creating a national strategy of 'active longevity', older people as a category remain a passive object of the external motivating efforts of the state or family. As Fedorova stated:

It's good if an elderly person has got grandchildren, children, friends, but if he is alone, then shuts down and goes into itself. It is needed to stir him up. Now various territorial and interest clubs are being created in the regional centres: singing, knitting, dancing, yoga, learning English, computers and much more. (BT, 06.11.2018).

An active lifestyle is promoted and supported by the state, whereas (as it is being presented in the official discourse) a passive life position is still dominant in society. The efforts public authorities are making and the initiatives being taken by local authorities to change this situation are not enough. All government agencies and local governments are developed, and the hypothetical narratives of potential outcomes illustrate the supposed perspectives. Thus, the new strategy is contrasted with negative public attitudes, and information is presented in the form of a story with a narrative of overcoming and a happy ending - solving the problem.

Another participant of the 'round table', A. Ezerin, director of the social and informational institution 'Urban Development', insists on the importance of changing age standards, which negatively affect the attitudes of Belarusians and illustrates his thesis by describing the usual stories of Belarusian men in retirement as "cease to set tasks for themselves, to reach heights" (BT, 06.11.2018). In this regard, Ezerin formulates a task for the media:

The vector of work is informational and is aimed at men who are $45+$. There are many advanced, charismatic people who continue to live actively in their 50s, 70s, and even 90s. Our task is to find and talk about them in the mass media, create social advertising, videos that show examples of active longevity. Older people do not interfere with uniting into initiatives and spending time together, participating in promotions. (BT, 06.11.2018) 
Thus, there are two distinct types of elderly people, one of which is active (unfortunately, the content put into the concept activity remains unknown), and the other, in the opinion of the author, needs to be activated and externally motivated, while the second type is much more numerous, since the active and energetic are invited to 'find' and present to the reader/viewer.

This topic of usefulness and the problem of dependency that opposes it is characteristic of the 'active longevity' narratives of officials and state experts. L. Zhilevich, Deputy Chief Doctor of the Clinical Hospital for Disabled People of the Great Patriotic War, Head of the State Gerontological Centre, Chief Geriatrist of the Ministry of Health, speaks about the dependent mentality of the elderly as a social problem:

Indeed, in my work I often come across a situation where older people consider themselves to be unnecessary to society. They do not know how to organize their lives in old age. So far, the mentality of an elderly person is as follows: he only expects benefits from the state, subsidies or other assistance. (BT, 06.11.2018)

It is important that this is stated by one of the future creators of the Belarusian 'active longevity' strategy, a person stating the need to educate Belarusian children in terms of the correct perception of an elderly person, people with disabilities, empathy and participation in helping such people. She insists that these older people need to be included in their work activities: "given that the number of older people will grow, the need to create jobs for them, and to increase employment will increase» (BT, 06.11.2018). Thus, not only political pressures, but also expectations (labour market activation) are emphasized in the power discourse of 'active longevity'.

A wide audience seems to be a problem, which is connected with the need to overcome social attitudes regarding relatively late age and stereotypes that exist in society and among elderly people in particular. The image of an elderly person in the statements of officials and official media materials is heterogeneous. There are references to the image of a 'typical', 'common', 'ordinary' elderly person and an emphasis on the qualities that characterize an 'atypical', 'exceptional' elderly person who surprises and serves as a model for other to follow. "There are older people you look at and admire. They are calm, tidy, wise, there is strength and kindness in their eyes. They have not turned into grunts-negativists or capricious helpless children." (BT, 18.08.2018). The author convinces the reader that there are older people who differ 
Official Media Discourse of 'Active Longevity': an Attempt to Popularize the Idea of the Inclusion of Older People into Society or to Conceal Undesirable Forced Choices

from the usual (according to the author) average person images i.e. negative images.

Zhilevich also uses the mobilizing potential of the 'active longevity' narrative. She states that a person's ageing is inevitable, but proper work with elderly patients will allow them to remain active members of society for a long time: "Elderly patients have from five to eight diseases. But this does not affect the quality of life of citizens. The main thing is to remain active, independent, 'the head of the centre asserts." (BT, 02.10.2018). This formulation again emphasizes the controllability of the aging processes, and also focuses attention on the role of motivation in achieving a high quality of life. Economic arguments also serve to popularize the idea of activism of older people:

Changes in pension systems are taking place in many countries. This is primarily due to the increase in life expectancy and the increase in the number of elderly people. In Belarus, the significant role of the state in ensuring a comfortable old age remains. At the same time, there is an opportunity to save money for living on a well-deserved rest. Do our citizens use this? (BT, 06.06.2018).

The improvidence and passivity of the elderly affect the quality of life not only of the pensioners themselves, but also of society as a whole, which is forced to activate the elderly, wasting their resources decreasing every year due to demographic processes. "Older people should remain in the labour market. Age is not a coordinate that is taken into account when we talk about work." (BT, 09.02.2017).

In turn, the state is doing everything possible to maintain a high quality of life for older people and their revitalization: rehabilitation and relaxation rooms, therapeutic and preventive physical education. The images of the Belarusian 'today' that elderly people offer (through mediation) expressed by journalists of the official media are bright and expressive: "At the age of 100 years to get over stenting of the coronary vessels. At the age of 101 - an operation in an oncologic dispensary. This is not news from foreign countries, but examples from our Belarusian medical practice." (BT, 26.09.2018). The material creates an image of practically omnipotent Belarusian medicine, finally levelling the negative influence of biological factors, removing old age and giving older people every opportunity for an active and fulfilling life. However, the expression "This is not news from foreign countries", emphasizing the significance of the progress in Belarusian medicine, also shows the journalist's uncertainty that the audience could believe that this is possible in Belarus. The author argues that with the help of this state-adjusted system, a person can and should control his life even at the 
latest age: "In our country a person is more protected, he has the opportunity to realize himself as a person, extend the retirement age, more in society, and all this in a complex is the component of the growth of life expectancy.» (BT, 14.04.2018).

All the problems of older people appear in a new light and no longer seem to be an alarming/critical issue, but easily corrected difficulties that an elderly person with the help of a modern and responsive Belarusian geriatric service could solve immediately. The dominant semantic line of this narrative is the thesis that old age is only an internal decision and individual laziness, passivity, because the state provides all the conditions for the longest and most active life of an elderly person. And since citizens have not yet understood this, it is necessary to find and exhibit to society examples of active older people and their secrets of longevity.

\section{THE STORIES OF INDIVIDUALS IN THE DISCOURSE ON 'ACTIVE LONGEVITY' IN OFFICIAL MEDIA}

In the course of reading and analysing the materials in each of the articles, one main topic was highlighted (if one main topic could not be singled out, 2 or 3 main issues were highlighted) in order to see a quantitative expression of the frequency of consecration in state press issues related to aging, older people and 'active longevity' during the analysed period.

Table 2

Main topics/issues associated with old age and active longevity in state media materials.

$\begin{array}{llll}\text { Topics/issues } & \text { BT } & \text { BelTA } & \text { Total }\end{array}$

State aid for older people (older people are

objects of guardianship)

32

21

53

Secrets of longevity (by experts)

22

8

30

Examples of active older people

18

5

23

About the strategy of 'active longevity'

9

7

16 
Official Media Discourse of 'Active Longevity': an Attempt to Popularize the Idea of the Inclusion of Older People into Society or to Conceal Undesirable Forced Choices

Socio-economic situation caused by demographic issues

10

9 experts)
'Silver economy'

Secrets of longevity (by people)

Child support

Sexual life of the aged

Barriers to active life

Reasoning about old age (journalists and

Note. Source: Field data.

A detailed study of the materials revealed that on the one hand, pensioners are displayed as objects of guardianship, dependent and unable to cope with everyday problems, to decide for themselves, but on the other hand - active, full of enthusiasm and energy. Dependency and vulnerability are presented as the result of passivity as a personal decision because a person's state of health can be controlled, if the person is hardworking and energetic. This duality of perception of the elderly in the official discourse can be traced in the texts devoted to the problems of 'active longevity' and thematically similar materials that could conventionally be entitled 'secrets of longevity'. Two main types of behaviour and two scenarios of living in late age clearly stand out in this discourse, however, both options are rarely mentioned by experts and authors in same text.

The heroes of the articles notice state efforts to ensure a high quality of life and active longevity and express gratitude:

I used to have everything - work, love, friends and the state, and now only the state remains (...) I owe the fact that I stand today on my feet to the state. All life in sanatoriums I was treated free of charge. And now, at best, I would be managing the wheelchair. (BT, 29.09.2018). 
At the same time, the interviewees improve their lives (actively): they create initiative groups for the improvement of households, work part time on the market, visit health centres for the elderly "And still there are so many things to do.» (BT, 27.10.2017).

According to V. Kovalkov, Deputy Minister of Labour and Social Protection, an increase in life expectancy is one of the reasons for raising the retirement age. He believes that raising the retirement age will not reduce the life expectancy of Belarusians, since: "As the experience of other countries shows, after the implementation of this measure, life expectancy is still growing, and the states make decisions on further raising the retirement age." (BelTA, 21.12.2016). Vital activity in this discourse corresponds to labour activity or socially useful activity, while activity in the labor market is determined as one of the key factors for longevity.

To maintain this thesis and change attitudes towards late retirement, there are also materials about older people who have worked arduously and diligently, retaining not only their working ability, but also a desire to work or make a contribution to housework. The stories of these people are motivating, since the reader from the mouth of these old age people receives confirmation that even heavy physical work in the difficult conditions of the past was feasible for active people. Therefore today, when conditions are more favourable than whenever during their working lives, people are able to work longer:

Edmund Ludvikovich Chaley from the village of Kalinovka celebrated his 93rd birthday this year, lives with his daughter, and is accustomed to work - life worked as a field farmer (...) Edmund Ludvikovich and now works as much as he can: he feeds goats, helps with housework, says that now life has become much easier: there is comfort in the house, and there is always a daughter with a son-in-law in case of bad health: - If it had been like this before, I would have 150 years to live. (BT, 27.10.2018).

The same idea is put forward in the article 'Fired due to old age. Forty-seven years ago', in which an elderly heroine shows her attitude to work and shows the capabilities of an elderly person. "In January, Anna Shatrova already celebrated her 101st anniversary. But the question of how much she still plans to live is answeredphilosophically: - How much God will give. But I would like to live a little longer.» (BT, 03.04.2017). The title of the article itself is ironic about the idea of retirement in 
Official Media Discourse of 'Active Longevity': an Attempt to Popularize the Idea of the Inclusion of Older People into Society or to Conceal Undesirable Forced Choices

connection with the attainment of an exact age after which a person can live actively for another 40 years. And the hero in another article, Nikolai Antonovich, speaks in support of the theory that it is hard work that contributes to longevity:

I worked a lot from an early age. Then - the war. Then I worked again, already in Baranavichy, at a furniture factory. Perhaps that is why I live so long. Now young people are lazy. There was a lot of technology, life has become more comfortable. Everything seems to be very good, but there is no movement... (BT, 08.06.2017)

Thus, not only the opportunity to work at retirement age, but also the desire to do so becomes the argument of the narrative. An additional argument is the thesis that longevity is the result of a long work experience.

The aged, old and advanced in years heroes of the interviews show that they are surprised by the substantial attention of correspondents to their age and insist that age is not an obstacle to an active life. Such materials are consistent with the objective of the media expressed in the framework of the official discourse that involves the search for and popularization of models of active ageing to follow. Interviews with active older people are one of the most popular topics (along with reports on state achievements in the field of social support for the elderly and their activity), which regularly appear in the media space of state-owned media.

Narratives of the official discourse present statistical data and expert conclusions according to which physicians, using a scientific approach to derive a formula for longevity, are accordant with stories of individuals of the third age that share their personal recipes for the elixir of youth. The findings are similar: the main component of longevity is an active and healthy lifestyle. Stories about active and busy old people, their positive attitude to life and to their age, illustrate the primacy of inner motivation and desire. Special attention is paid to the presence of favourable conditions: the efforts of physicians and the achievements of medicine to maintain the quality of life of an aged person and his social inclusion.

I always wondered how people could sit at home without fear of sight. One must walk, enjoy the sun, sky, fresh air, communicate with nature! - even now, having almost completely lost sight, Ekaterina Mikhailovna walks with her daughter Lyudmila several hours a day. After 40 years she devoted her life to a summer 
cottage as a teacher of mathematics, retired. Only in 92 years she had to give up her hobby for health reasons, but now the former teacher finds herself. (BT, 08.06.2017)

There are plenty of examples to look back on and motivations if they are required, "They could, now it's your turn». However, examples of such activity are not perceived as ordinary, ubiquitous by journalists and their interlocutors. The stories of older people are presented as exceptional, outstanding from the crowd, nontrivial:

I remember one amazing patient who entered the hospital with a few manifestations of coronary artery disease and was quickly discharged. Man 93 years. Up to 90 years, he taught at BNTU. In retirement, wrote five books. One of them is about God, and five, imagine, about love! It turns out that he adored all his life and idolized his spouse, who had already passed away, and wrote about his feelings for her. He said that all his life he was a workaholic. Always active not only intellectually, but also physically. For myself, I chose swimming and Nordic walking. These are the examples that delight and delight. (BT, 18.08.2018)

Thus, the narrative of 'active longevity' is constructed rather as a counter-narrative, designed to overcome the opposite, dominant in society. With such stories of exceptional people, journalists try to present arguments for maintaining activities familiar to a person into old age and to convince the audience. However, the admiring surprise at the stories of the interviewed older people underlines how unpopular and unusual/uncommon/atypical such stories are and how far they are out of the general range of views in modern Belarusian society.

Trying to break stereotypes about older people, journalists themselves use expressions that contradict the message of the material and reinforce negative social attitudes. For example, the age is mentioned as something defamatory, something that is customary to hide:

Usually it's not customary to talk about the age of women, even congratulating on the anniversary, we somehow try not to mention the number of years lived. But in the case of Minsk woman Polina Katsuba that is above 90 years old, age is a reason for pride - in its physical form and life optimism, it can easily give young people a head start. (BelTA, 13.03.2018) 
Official Media Discourse of 'Active Longevity': an Attempt to Popularize the Idea of the Inclusion of Older People into Society or to Conceal Undesirable Forced Choices

At the same time, if older people are actively involved in labour for the benefit of society, their age is mentioned and becomes a reason for prise. Such activity brings not only psychological satisfaction, but also improves physical conditions. The stories of journalists' interlocutors convince us that a positive attitude and activity have a significant effect on health and allow a person to forget about age. "I am healthier today. (...) If someone had told me that I will dance, I would not have believed in it. My friends are shocked!" (BelTA, 08.03.2018). That is, a person through his or her wilful decision and choice in favour of activity overcomes health problems that previously seemed inevitable to them at their age.

\section{DISCUSSIONS AND CONCLUSIONS}

We can agree with the statement of Harbison \& Morrow (1998) that older people are presented in connection with dichotomous oppositions 'healthy' - 'painful', 'dependent' - 'independent', 'burden' - 'self-sufficient'. In this case, we were interested in dichotomous oppositions to the concept of 'active', used to define an old age person, and to the concept of 'active ageing/longevity' used in the framework of official discourse. For the narratives of 'active longevity' in the official discourse, the dichotomies 'active' - 'passive', 'useful' - 'dependent', 'motivated' - 'unmotivated' are also characteristic. Such a monochrome picture looks like a simplified version of reality, which does not reflect it accurately, but constructs a frame of reality. Moreover, the frequent identification of the vital activity as labour activity in this discourse aggravates the artificial separation of non-working aged from the rest of 'useful' groups of society. As the researchers note, "an exclusive focus on employment is problematic, as it reduces the complexity of ageing to a single component» so it becomes synonymous with 'productive ageing' (Giorgi, 2005 as cited in Boudiny \& Mortelmans, 2011, p. 8).

According to Matyok, counter-narratives "challenge cultural stereotypes and create new ways of seeing the world" (Matyok, 2009, p.8). Likewise, Rimstead (1996) states that a counter-narrative re-humanizes, "democratizes peace-making activities by giving silenced individual a public forum", but in the case considered here, the humanistic component of the goals of breaking stereotypes about old age as a time of welldeserved rest and avoiding active participation in the labour market is that under research scrutiny. Is the consolidation of a new social construct about the necessity 
of remaining useful for society a form of aggravation of inequality and deterioration in the quality of life of the elderly? (Giorgi, 2005; Walker, 2006).

If, "voice is power, storytelling - which facilitates voice - is empowering" (Sehmi, 2000 , p. 8), then the selection of stories shown votes only in favour of one idea, thus making invisible those who don't fit into the desired state concept. We can agree with the statement of Fisher (2010) that, "discourse legitimizes patterns of (in)visibility and (in)equality that contribute to the legitimization of capitalist socio-political order" That is why it is important either what is revealed or what is hidden (Stochetti, 2014; 2018). Furthermore, invisibility is related to injustice, and it would be very useful to conduct a quantitative study of the representation of older people in the Belarusian discourse and that share of the discussed problems related to this group of people presented in media materials. Quantitative content analysis would allow to measure the intensity of certain narratives in the official discourse of 'active longevity'. It would also be interesting to investigate the frequency of visibility of older people in media materials, how much their problems are presented in the information field (see examples of the three countries of Bulgaria, Serbia and Portugal in Raycheva, Tomov, Amaral, Petrović, Vukelić, \& Čizmić, 2018).

The idea of 'active longevity' is popularized by the official Belarusian media following the voiced objective of activating older people for inclusion in the life of society. In the materials of the official media, there are arguments defending the interests of society (economic contribution, social utility of the elderly), as well as a focus on benefits/outcomes for the elderly themselves (health, longevity, sense of self-worth). However, broadcast structured stories, scenarios (disputes with theses and conclusions regarding 'active longevity'), other narrative scenes, not necessarily having the structure and form of a complete story (nonstories) - all along with the comments of journalists, show a preferred version of reality, as well as the rarity and non-proliferation of this choice in modern Belarusian society. This suggests that in this discourse it is the official narrative of 'active longevity' that is the counter-story, designed to overcome the dominant in society, popular and shared by most of the narratives.

In this discourse, there are no stories of people for whom the continuation of labour activity after retirement is an undesirable, forced decision. Economic difficulties are experienced only by the Belarusian economy that bears the burden of paying social benefits and organizing medical and social assistance. And the heroes of the stories, and the comments of journalists and experts do not contain arguments in favour of 
Official Media Discourse of 'Active Longevity': an Attempt to Popularize the Idea of the Inclusion of Older People into Society or to Conceal Undesirable Forced Choices

improving the quality of life of older people through increasing pension payments. There are no critical comments on the current pension system and its possible changes in general; the main objects of criticism are dependency and passivity.

Typical of the language in these materials is the positioning of the elderly in an unequal position, in a position as objects of care, guardianship, motivation (external influence). The knowledge of passivity, inertia of the elderly and an unfriendly attitude towards them is introduced as assumed by and shared in society, and this is contrasted with the highlighted active, successful personalities of some elderly.

By using the 'soft power' instrument, the state motivates the elderly person, creates conditions for active longevity, however, also admits that only a small proportion of the elderly are active and energetic. The main obstacles to the activity of the elderly in this discourse are their passivity, an unwillingness to change attitudes, and the need for retraining. Diseases and destructive physical processes are not considered in the context of barriers to activities by the elderly.

What is the official discourse of 'active ageing'/active longevity' struggling with? With a stereotype about the passivity of the elderly or with their right to passivity? It is difficult to unequivocally answer this question. Alternative stories should be presented and other voices heard in order to provide not only an 'expert' perspective. In this way, each individual would have the right to choose and be fully aware about the choices available to them.

\section{REFERENCES}

Balmaceda, M.M. (2014). Living the High Life in Minsk: Russian Energy Rents, Domestic Populism and Belarus' Impending Crisis High. Central European University Press, $236 \mathrm{p}$.

Bamberg, M. \& Andrews, M. (Eds.) (2004). Considering counter-narratives: Narrating, resisting, making sense. Amsterdam: John Benjamins.

Bassuener, K. (2013). Belarus: Europe's Last Dictatorship. In J. Kinsman, K. Bassuener (Eds.), A diplomat's handbook. For democracy development support, (pp. 331351). Third edition. 
Belarusian Association of Journalists (2019). "Forced subscription to newspapers is a Soviet anachronism," human rights activist Stefanovich/"Принудительная подписка на газеты - советский анахронизм", - правозащитник Стефанович. Retrieved from https://baj.by/ru/analytics/prinuditelnayapodpiska-na-gazety-sovetskiy-anahronizm-pravozashchitnik-stefanovich

Belarusian Association of Journalists. (2019). Special Issue: Results of the Year 2018 in Figures. Mass Media in Belarus, 1(57) [E-Newsletter]. Retrieved from https:// baj.by/sites/default/files/analytics/files/smi-01572019-en.pdf

Belarusian Association of Journalists. (2016, April - June). Mass Median on the Eve of Parliamentary Elections - 2016. Mass Media in Belarus Bulletin 2(48). [E-Newsletter]. Retrieved from https://baj.by/en/analytics/e-newsletter-massmedia-belarus-bulletin-248-mass-media-eve-parliamentary-elections-2016

Bennett, W.L, \& Entman, R.M. (Ed.). (2001). Mediated Politics: Communication in the Future of Democracy. Cambridge: Cambridge University Press.

Berger, J., Quinney, R. (Eds.) (2004). Storytelling Sociology: Narrative as Social Inquiry. Rienner Publisher.

Blumler, J. G., \& Kavanagh, D. (1999). The Third Age of Political Communication: Influences and Features. Political Communication, 16, 209-230.

Boudiny, K. (2013). 'Active ageing' from empty rhetoric to effective policy tool. Ageing \& Society, 33, 1077-1098.

Boudiny, K., Mortelmans, D. (2011). A critical perspective: Towards a broader understanding of 'active ageing'. Electronic Journal of Applied Psychology, 7(1), 8-14.

Chulitskaya, T. (2014). The narratives of social justice in a non-democratic regime: an analysis of the case of Belarus/Socialinio teisingumo naratyvai nedemokratinio režimo sqlygomis: Baltarusijos atvejo analizè. (Unpublished doctoral dissertation). Vilnius University and Lithuanian Social Research Centre, Lithuania.

Committee to Protect Journalists (2019, May 3) Belarus: Use Europe to Spur Media Freedom. Retrieved from https://cpj.org/2019/05/belarus-european-games-eocjournalist-hotline.php 
Official Media Discourse of 'Active Longevity': an Attempt to Popularize the Idea of the Inclusion of Older People into Society or to Conceal Undesirable Forced Choices

Czarniawska, B. (2004). Narratives in Social Science Research. Introducing Qualitative. Methods. London: Sage Publications.

Fisher, E. (2010). Contemporary Technology Discourse and the Legitimation of Capitalism. European Journal of Social Theory, 13(2), 229-252.

Fisher, W. R. (1978). Toward a logic of good reasons. Quarterly Journal of Speech, 64(4):376-384.

Fisher, W. R. (1984). Narration as a human communication paradigm: The case of public moral argument. Communication Monographs, 51(1), 1-22.

Fisher, W. R. (1987). Numan communication as narration: Toward a philosophy of reason, value, and action. Columbia, S.C.: University of South Carolina Press.

Foucault, M. (1991). Governmentality. In C. Gordon, G. Burchell, P. Miller, \& M. Foucault, The Foucault effect: studies in governmentality: with two lectures by and an interview with Michel Foucault (pp. 87-104). London, Harvester/Wheatsheaf.

Gans, H. (2003). Democracy and the News. New York: Oxford University Press.

Giorgi, L. (2005). Overcoming the barriers and seizing the opportunities for active ageing policies in Europe. Brussels: European Commission.

Graber, D.A., \& Dunaway, J. (2017). Mass Media and American Politics. CQ Press..

Grodno Regional Executive Committee (2018). Alexander Lukashenko on the role of the media: it is not the fact that nuclear weapons are more powerful/Александp Лукашенко о роли СМИ: не факт, что ядерное оружие мощнее. Retrieved from https://grodnorik.gov.by/ru/republic-ru/view/aleksandr-lukashenko-oroli-smi-ne-fakt-chto-jadernoe-oruzhie-moschnee-2235-2018/

Gunther, A.C., \& Douglas Storey, J. (2003). The Influence of Presumed Influence. Journal of Communication, 53(2), 199-215.

Harbison, J., \& Morrow, M. (1998). Re-examining the social construction of elder abuse and neglect: A Canadian perspective. Ageing \& Society, 18(6), 691-711.

Human Rights Center Viasna (2016). Human Rights Situation in Belarus in 2016: Analytical Review. Retrieved from https://spring96.org/files/misc/review 2016 en.pdf 
Human Rights Center Viasna (2018). Human Rights Situation in Belarus: 2018. Retrieved from http://spring96.org/en/news/90469

Konstantinov, G./Константинов, Г. (2009, April 16). The popularity of online media is growing in Belarus/B Беларуси растет популярность интернет-СМИ. Deutsche Welle. Retrieved from https://www.dw.com/ru/в-беларуси-растетпопулярность-интернет-сми/а-4183812

Larson, E. V., Darilek, R. E., Gibran, D., Nichiporuk, B., Richardson, A., Schwartz, L.H., \& Thurston, C. Q. (2009). Foundations of Effective Influence Operations. A Framework for Enhancing Army Capabilities. Santa Monica, CA: RAND Corporation. Retrieved from https://www.rand.org/pubs/monographs/MG654. $\underline{\mathrm{html}}$

Macnamara, J. (2005). Media content analysis: Its uses; benefits and best practice methodology. Asia Pacific Public Relations Journal, 6(1), 1-34.

Matyok, T. G. (2009). Constructing counter-narrative: A key to changing neo-slavery in the de-nationalized world of globalization - the shipping industry and the case of the M/V Agios Minas. University of North Carolina at Greensboro.

Mayhew, L. H. (1997). The new public: Professional communication and the means of social influence. Cambridge, England: Cambridge University Press.

Merlo-Ponti, М./Мерло-Понти, М. (1996). In defence of philosophy/B защиту философии. Москва: Издательство гуманитарной литературы.

Mishler, E. G. (1986). Research interviewing: Context and narrative. Cambridge, MA: Harvard University Press.

Miskimmon, A. (2013). Strategic narratives. Communication power and the new world order. New York.

Neuman, W. (1997). Social research methods: qualitative and quantitative approaches. Needham Heights, MA: Allyn \& Bacon.

Nye, J. S. (1990). Soft Power. Foreign Policy, 80, 153-171.

Nye, J.S. (2006). Think Again: Soft Power. Foreign Policy, February, 23. 
Official Media Discourse of 'Active Longevity': an Attempt to Popularize the Idea of the Inclusion of Older People into Society or to Conceal Undesirable Forced Choices

Official website of the Republic of Belarus (2019). Mass media in Belarus. Retrieved from https://www.belarus.by/en/about-belarus/mass-media-in-belarus

Pentland, A. (2014). Social Physics: How Good Ideas Spread - the Lessons from a New Science. Penguin: London.

Pollner, M., Stein J. (1996). Narrative mapping of social worlds: the voice of experience in alcoholics anonymous. Symbolic Interaction 19(3), pp. 203-223.

Porche, I.R. (2013). Redefining information warfare boundaries for an army in a wireless world. Santa Monica.

Presidential Decree No 570 (2014, December 8). Concerning the improvement of pension provision system. Retrieved from http://president.gov.by/en/official documents en/view/decree-no-570-of-8-december-2014-10386/

Raycheva, L., Tomov, M., Amaral, I., Petrović, I., Vukelić, I., \& Čizmić, S. (2018). Ageing Women in the Media Mirror Maze. Media Environment, Public and Strategic Communication, 39-47. Izdatelski kompleks - UNSS.

Reporters Without Borders (2019). 2019 World Press Freedom Index. Retrieved from https://rsf.org/en/ranking\#

Rimstead, R. (1996). Mediated lives: Oral histories and cultural memory. Essays on Canadian Writing, 60, 139-165.

Roselle, L., Miskimmon, A., \& O’Loughlin, B. (2014). Strategic narrative: A new means to understand sopt power. Media, War \& Conflict, 7(1), 70-84.

Roy, E. (1994). Narrative Policy Analysis. London: Duke University Press.

Ryan, M.-L., \& Thon, J.-N. (2014). Storyworlds Across Media. University of Nebraska Press, 380 pp.

Stochetti, M. (2014). Images and Power in the Digital Age: The Political Role of Digital Visuality. KOME. An International Journal of Pure Communication Inquiry, 2(2), $1-16$.

Stochetti, M. (2018). Invisibility, Inequality and the Dialectics of the Real in the Digital Age. Interações: Sociedade e as novas modernidades 34, 23-46. 
Vitto, V. (2001, October). Report of the Defence Science Board Task Force on Managment Information . Washington D. C.: DSBTF\&MI.. Retrieved from http://www.acq. osd.mil/dsb/reports/ADA396312.pdf

Walker, A. (2006). Active ageing in employment: Its meaning and potential. Asia Pacific Review, 13(1), 78-93.

WHO (2002). Active Ageing. A Policy Framework. World Health Organisation, Geneva.

Williams, B. A., \& Michael, X. D. C. (2011). After Broadcast News: Media Regimes, Democracy, and the New Information Environment. New York: Cambridge Univeristy Press.

\section{Periodicals:}

BelTA/БелТА (2016, December 21). Raising the retirement age will not hit the life expectancy of Belarusians - Kovalkov/Повышение пенсионного возраста не ударит по продолжительности жизни белорусов - Ковальков. Retrieved from https://www.belta.by/society/view/povyshenie-pensionnogo-vozrasta-neudarit-po-prodolzhitelnosti-zhizni-belorusov-kovalkov-224826-2016/

Belarus Today/Беларусь Сегодня (2017, February 9). On the bright side of demographics. Experts - about the new state program of demographic security of the country/На светлой стороне демографии. Эксперты - о новой госпрограмме демографической безопасности страны. Retrieved from https://www.sb.by/ articles/na-svetloy-storone-demografii.html

Belarus Today/Беларусь Сегодня (2017, April 3). Fired due to old age. Forty seven years ago/Уволена по старости. Сорок семь лет назад. Retrieved from https:// www.sb.by/articles/uvolena-po-starosti-sorok-sem-let-nazad.html

Belarus Today/Беларусь Сегодня (2017, June 8). Hundred years in motion/Cmo лет в движении. Retrieved from https://www.sb.by/articles/sto-let-v-dvizhenii.html

Belarus Today/Беларусь Сегодня (2017, October 27). The most golden age/Самыцй золотой возраст. Retrieved from https://www.sb.by/articles/samyy-zolotoyvozrast.html 
Official Media Discourse of 'Active Longevity': an Attempt to Popularize the Idea of the Inclusion of Older People into Society or to Conceal Undesirable Forced Choices

BelTA/БелTA (2018, March 8). REPORT: Age is not an obstacle: Minsk pensioners are actively engaged in yoga and Indian dances/ РЕПОРТАЖ: Возраст не помеха: минские пенсионерки активно занимаются йогой и индийскими танцами. Retrieved from https://www.belta.by/special/regions/view/reportazh-vozrastne-pomeha-minskie-pensionerki-aktivno-zanimajutsja-jogoj-i-indijskimitantsami-293282-2018/

BelTA/БелТА (2018, March 13). Minsk woman in 85 years old wins marathons and is going to the Galkin show/Минчанка в 85 лет побеждает в марабонах и собирается на шоу к Галкину. Retrieved from https://www.belta.by/special/ interview/view/minchanka-v-85-let-pobezhdaet-v-marafonah-i-sobiraetsjana-shou-k-galkinu-6118/

Belarus Today/Беларусь Сегодня (2018, April 14). Major geriatrist of the Ministry of Health Lyudmila Zhilevich: "Old age can come in 40 years if you have forgotten how to look at the world positively"/Главный внештатный гериатр Минздрава Людмила Жилевич: «Старость может наступить и в 40 лет, если вы разучились смотреть на мир позитивно». Retrieved from https://www.sb.by/ articles/glavnyy-vneshtatnyy-geriatr-minzdrava-lyudmila-zhilevich-starostmozhet-nastupit-i-v-40-let-esli-vy-.html

Belarus Today/Беларусь Сегодня (2018, June 6). Money love the bill. Pension in the size of an average salary: how to ensure a comfortable old age?/Деньги любят счет. Пенсия размером в среднюю зарплату: как обеспечить себе безбедную cmapocms? Retrieved from https://www.sb.by/articles/dengi-lyubyatschet523625.html

Belarus Today/Беларусь Сегодня (2018, August 18). 'Do not envy anyone and love life'/ «Никому не завидуйте и любите жизнь» Простье правила продлить свой век подсказала читателям "СГ» геронтолог. Retrieved from https:// www.sb.by/articles/nikomu-ne-zaviduyte-i-lyubite-zhizn.html

Belarus Today/Беларусь Сегодня (2018, September 26). Age does not matter/ Возраст значения не имеет. Retrieved from https://www.sb.by/articles/ vozrast-znacheniya-ne-imeet.html 
Belarus Today/Беларусь Сегодня (2018, September 29). Gray legends. What is the average portrait of a nursing home dweller?/Седые легенды. Как выглядит среднестатистический портрет обитателя дома престарельх. Retrieved from https://www.sb.by/articles/sedye-legendy324.html

Belarus Today/Беларусь Сегодня (2018, October 2). Belarus wants to expand geriatric care/ В Беларуси хотят расширить службу гериатрической помощи. Retrieved from https://www.sb.by/articles/v-belarusi-khotyat-rasshiryatsluzhbu-geriatricheskoy-pomoshchi.html

Belarus Today/Беларусь Сегодня (2018, October 27). Gene rural longevity/Ген сельского долголетия. Retrieved from https://www.sb.by/articles/gen-selskogodolgoletiya.html

Belarus Today/Беларусь Сегодня (2018, November 6). These are our years/Taкие наши годьı. Retrieved from https://www.sb.by/articles/takie-nashi-gody.html

Republic/Рэспубліка. (2018, December 29). Ирина Костевич - о столетнем юбилее системь органов по труду и соизащите, идеальной модели семьи и стратегии активного долголетия. Retrieved from http://pravo.by/novosti/ obshchestvenno-politicheskie-i-v-oblasti-prava/2018/december/31971/ 